\title{
Pengaruh konduktivitas thermal pada hot cylinder mesin stirling menggunakan energi surya terkonsentrasi
}

\author{
Akhmad Rizal Fanani ${ }^{1}$, Muhammad Agus Sahbana ${ }^{2}$, Purbo Suwandono ${ }^{3^{*}}$ \\ 1,2 Teknik Mesin, Fakultas Teknik, Universitas Widyagama Malang \\ ${ }^{3}$ D3 Mesin Otomotif, Fakultas Teknik, Universitas Widyagama Malang \\ Jalan borobudur No 35, Malang, Indonesia \\ *Corresponding author: purbo@widyagama.ac.id
}

\begin{abstract}
Renewable energy is one of the businesses sector that will develop rapidly after the changing economic order due to the corona outbreak. The characteristics of Indonesia's tropical climate by getting good sunlight throughout the year can be used as alternative and renewable energy. The Stirling engine is one type of external combustion engine, because combustion is carried out outside the engine using a closed regenerative cycle in which the working fluid is compressed or expanded in a separate reservoir and then distributed to drive the power piston reciprocatingly. The method developed is the use of solar energy which is concentrated by a parabolic reflector to the hot cylinder of the Stirling engine to convert heat energy into motion energy. The purpose of this study was to determine the effect of the thermal conductivity of several material specimens used in the hot cylinder of the Stirling engine including copper, stainless steel, \& glass. This study uses an experimental method to describe the performance of a stirling engine prototype using various types of hot cylinder material specimens. The results showed that the gamma stirling engine using hot cylinder glass material had the best performance because with a heat conductivity of $0.78 \mathrm{~W} / \mathrm{m}^{\circ} \mathrm{C}$ it was able to drive a stirling engine with a speed of $132 \mathrm{rpm}$ and a torque of $0.57 \mathrm{~N} . \mathrm{mm}$ at the temperature difference between hot cylinder and cold cylinder of $88^{\circ} \mathrm{C}$ and with a thermal efficiency of $20.39 \%$.
\end{abstract}

Keywords: renewable energy, thermal conductivity, energy conversion, stirling engine

\section{Abstrak}

Energi terbarukan merupakan salah satu sektor bisnis yang akan berkembang pesat setelah berubahnya tatanan perekonomian akibat wabah corona. Karakteristik iklim tropis Indonesia dengan mendapatkan penyinaran sinar matahari yang baik sepanjang tahun bisa dimanfaatkan sebagai energi alternatif dan terbarukan. Mesin Stirling merupakan salah satu jenis motor bakar pembakaran eksternal, karena pembakaran dilakukan di luar mesin dengan menggunakan siklus regeneratif tertutup di mana fluida kerja akan terkompresi atau terekspansi pada reservoir yang terpisah kemudian di distribusikan untuk menggerakan piston daya secara reciprocating. Metode yang dikembangkan adalah pemanfaatan energi surya yang dikonsentrasikan oleh parabola reflektor menuju hot cylinder mesin stirling untuk mengkonversi energi panas menjadi energi gerak. Tujuan penelitian ini adalah untuk mengetahui pengaruh konduktivitas termal dari beberapa spesimen material yang digunakan pada hot cylinder mesin stirling meliputi copper, stainless steel, \& glass. Penelitian ini menggunakan metode eksperimen untuk mendiskripsikan unjuk kerja prototipe mesin stirling menggunakan berbagai jenis spesimen material hot cylinder. Hasil penelitian menunjukan mesin stirling tipe gamma dengan menggunakan material hot cylinder glass memiliki performa terbaik karena dengan konduktivitas panas sebesar $0,78 \mathrm{~W} / \mathrm{m}^{\circ} \mathrm{C}$ mampu menggerakan mesin stirling dengan kecepatan $132 \mathrm{rpm}$ dan torsi $0,57 \mathrm{~N} . \mathrm{mm}$ pada perbedaan temperatur antara hot cylinder dan cold cylinder sebesar $88^{\circ} \mathrm{C}$ serta dengan efisiensi termal sebesar 20,39\%.

Kata kunci: energi terbarukan, konduktivitas termal, koversi energi, mesin stirling. 


\section{Pendahuluan}

Mengacu pada pernyataan kementrian Energi dan Sumber Daya Mineral (ESDM) bahwa di era setelah berubahnya tatanan perekonomian akibat wabah corona ada 5 bisnis yang bakal bersinar di masa depan. [1] Salah satunya adalah energi terbarukan atau renewable energy. Sebenarnya konsep tersebut sudah mulai dikenal pada tahun 1970-an sebagai upaya dalam mengimbangi energi berbahan bakar nuklir dan fosil. Namun di era yang serba modern seperti saat ini konsep pembaharuan energi lebih dituntut untuk mengembangkan sumber energi alternatif yang inovatif. Salah satunya adalah pemanfaatan energi termal yang bersumber dari radiasi matahari.

Negara Indonesia merupakan negara yang memiliki karakteristik iklim tropis yang terletak di bawah garis katulistiwa dan dilalui angin muson timur yang berhembus dari benua Australia menuju Asia, sehingga wilayah Indonesia mengalami musim kemarau dan memperoleh penyinaran sinar matahari yang baik sepanjang tahunnya [2]. Meningkatnya jumlah penduduk dan semakin banyak industri yang berkembang, mengakibatkan kebutuhan energi semakin lama semakin meningkat [3]. Dengan adanya beberapa faktor tersebut sebuah terobosan untuk membuat teknologi tepat guna berupa mesin stirling dengan input sumber panas yang berasal dari pantulan parabola reflektor adalah salah satu cara yang dapat dikembangkan sebagai pemanfaatan energi terbarukan.

Mesin stirling merupakan salah satu jenis motor bakar pembakaran eksternal, karena pembakaran dilakukan di luar mesin [4]. Mesin stirling ditemukan oleh Dr. Robert Stirling pada tahun 1816. Mesin menggunakan siklus regeneratif tertutup, di mana fluida kerja akan terkompresi atau terekspansi pada reservoir yang terpisah kemudian didistribusikan untuk menggerakan piston daya secara reciprocating.

Pada penelitian ini akan dikaji mengenai pengaruh konduktivitas termal dari beberapa spesimen material yang digunakan pada hot cylinder mesin stirling menggunakan energi surya terkonsentrasi. Sehingga dalam perencanaannya bisa diketahui penggunan material mana yang lebih efisien sebagai hot cylinder mesin stirling. Adapun jenis material yang akan digunakan meliputi : copper, stainless steel, \& glass.

Konduktivitas termal adalah ukuran kemampuan suatu material atau bahan dalam menghantarkan energi. [5] Energi termal dihantarkan dalam bentuk zat padat melalui pergerakan elektron bebas. Suatu material disebut memiliki konduktivitas yang baik apabila terdapat elektron yang bergerak didalam struktur kisi bahan, maka elektron itu disamping dapat mengangkut muatan listrik dapat pula berfungsi sebagai penerus energi termal dari area yang bersuhu tinggi menuju area yang bersuhu rendah.

Dari penelitian terkait pengembangan mesin stirling sebagai pembangkit energi listrik telah banyak dilakukan, diketahui mesin stirling dengan tipe gamma memiliki efisiensi tertinggi pada suhu operasi yang rendah.[6]. Hal ini disebabkan karena mesin stirling tipe gamma memiliki luas penukar panas dan penukar dingin yang lebih besar daripada ukuran piston sehingga volume ruang gas untuk berekspansi relatif lebih besar dan proses transfer daya mekanik oleh gas menjadi lebih efisien. Efisiensi bisa lebih ditingkatkan lagi apabila ada pengaruh perubahan temperatur yang signifikan antara hot cylinder (displacer) dengan cold cylinder.

\section{Tinjauan Pustaka}

Achmad Zayyinun N dan Mahendra Widyaratono pada tahun 2020 melakukan penelitian tentang prototipe mesin stirling menggunakan panas sinar matahari sebagai energi alternatif. Dihasilkan bahwa unjuk kerja reflektor parabolik mampu meningkatkan intensitas panas cahaya matahari dengan perbesaran rata-rata 1,2 kali pada setiap jam. Unjuk kerja prototipe mesin stirling menggunakan panas sinar 
matahari sebagai energi alternatif juga mampu bekerja pada jam 11.00 dengan suhu $136^{\circ} \mathrm{C}$, kecepatan putaran $751 \mathrm{rpm}$, mengeluarkan tegangan 0,89 volt dan mendapatkan suhu paling tinggi dijam 12.00 dengan suhu $188^{\circ} \mathrm{C}$, kecepatan putaran 823 rpm, mengeluarkan tegangan 1,12 volt. [7]

Alfianti, dkk pada tahun 2016 mendesain dan membuat mesin stirling tenaga matahari dengan memanfaatkan pemanas matahari tipe box untuk pembangkit listrik. Metode penelitian yang dilakukan secara eksperimental, yaitu untuk menguji mesin stirling. Sedangkan tujuan penelitiannya adalah untuk mengetahui intensitas matahari terhadap perbedaan suhu, pengaruh perbedaan suhu terhadap putaran dan efisiensi yang dihasilkan oleh mesin stirling. Hasil yang didapatkan adalah efisiensi paling tinggi yaitu $12.1 \%$ dari 834 $\mathrm{W} / \mathrm{m}^{2}$ dengan perbedaan suhu $120^{\circ} \mathrm{C}$ sehingga menghasilkan putaran $139 \mathrm{rpm}$ dengan daya generator yang dihasilkan yaitu 0.004 Watt. [9]

Penelitian yang sudah dilakukan oleh Hari S. Ritonga, Farel H. Napitupulu, dkk, pada tahun 2019 tentang rancang bangun mesin stirling tipe gamma berkapasitas $157 \mathrm{ml}$ yang menggunakan pendingin cairan didapatkan kesimpulan bahwa penggunaan pendingin cairan pada mesin stirling akan meningkatkan performa dan daya mesin. [10]

Siddiqui, dkk pada tahun 2015 melakukan penelitian tentang pengaruh sudut fase terhadap efisiensi dari mesin stirling tipe beta, yaitu optimasi dan pemodelan sudut fase dari mesin stirling tipe beta silinder tunggal dengan helium sebagai fluida kerja. Metode yang digunakan adalah dengan menggunakan analisis Schmidt untuk menganalisa efisiensi keluaran dari mesin stirling. Hasil penelitian menunjukkan bahwa sudut fase yang cocok untuk efisiensi maksimum adalah $90^{\circ}$. [11]

Imhamed M. Saleh, dkk pada tahun 2016 telah melakukan penelitian terkait pengembangan desain dan fabrikasi konsentrator parabola surya bertipe dish untuk pembangkit uap. Kesimpulannya pengaturan eksperimental terdiri dari piringan parabola sistem konsentrator surya dibuat dengan cermin yang sangat reflektif. Panas terkonsentrasi diserap oleh tabung tembaga terdiri dari kumparan dalam bentuk melengkung dan dipasang pada jalur jejak matahari untuk mendapatkan energi matahari yang maksimal. Konsentrator surya parabola dengan diameter 2,4 meter mampu mencapai suhu maksimum sebesar $635^{\circ}$ C. [12]

Irnin Agustina Dwi Astuti pada tahun 2015 melakukan penelitian terkait penentuan konduktivitas termal logam tembaga, kuningan, dan besi dengan metode gandengan didapat kesimpulan tembaga memiliki kondukivitas panas sebesar 346 $\mathrm{W} / \mathrm{m} .{ }^{\circ} \mathrm{K}$, kuningan sebesar $120 \mathrm{~W} / \mathrm{m} .{ }^{\circ} \mathrm{K}$, \& besi sebesar $80 \mathrm{~W} / \mathrm{m} .{ }^{\circ} \mathrm{K} \quad$ [13].Material tembaga menunjukan konduktivitas termal tertinggi diantara lainnya. Penentuan konduktivitas termal material tersebut dilakukan menggunakan elemen pemanas (nikelin) yang dililitkan pada material spesimen. Kemudian divariasi nilai tegangan listrik untuk diketahui besar arus keluarannya dan diukur perbedaan suhu pada ujung-ujung material.

Penelitian yang sudah dilakukan oleh Syafriyudin, dkk pada tahun 2013 tentang pembangkit listrik tenaga matahari berbasis mesin stirling untuk skala rumah tangga, dimana desain optimum dari reflektor solar dan panas optimum dengan menggunakan mesin stirling tipe gamma. Di dapatkan hasil yang mengindikasikan bahwa temperatur reflektor yang proporsional dari silinder panas mesin stirling tipe gamma menghasilkan panas tertinggi pada suhu $137,4{ }^{\circ} \mathrm{C}$ dan dapat mengerakkan mesin stirling dengan kecepatan 200 rpm selama 20 detik. [14]

Berdasarkan informasi dari penelitian yang telah dilakukan tersebut maka dalam penelitian kali ini tujuan yang ingin didapatkan adalah untuk mengetahui unjuk kerja mesin stirling tipe gamma menggunakan energi surya terkonsentrasi dan untuk menganalisis pengaruh konduktivitas termal pada mesin stirling 
terhadap output berupa rpm, torsi, dan efisensi.

\section{Metode Penelitian}

Penelitian ini dilakukan dengan metode eksperimen. Penelitian eksperimen merupakan metode sistematis yang berfungsi untuk membangun hubungan yang mengandung fenomena sebab akibat. Penelitian eksperimen merupakan metode utama dari model penelitian yang menggunakan sistem pendekatan kuantitatif dengan tujuan untuk mengetahui pengaruh konduktivitas termal pada hot cylinder mesin stirling menggunakan energi surya terkonsentrasi.

\section{Diagram alir penelitian}

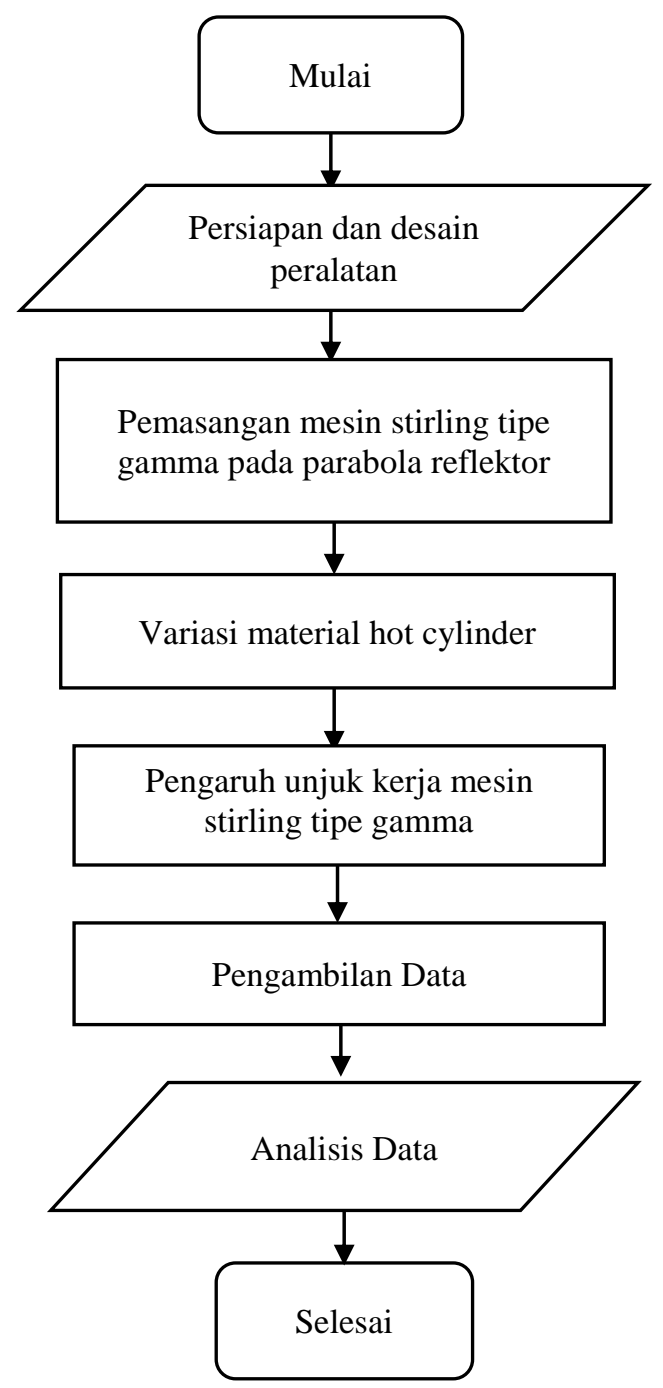

\section{Desain Rangkaian Alat}

a. Parabola reflektor

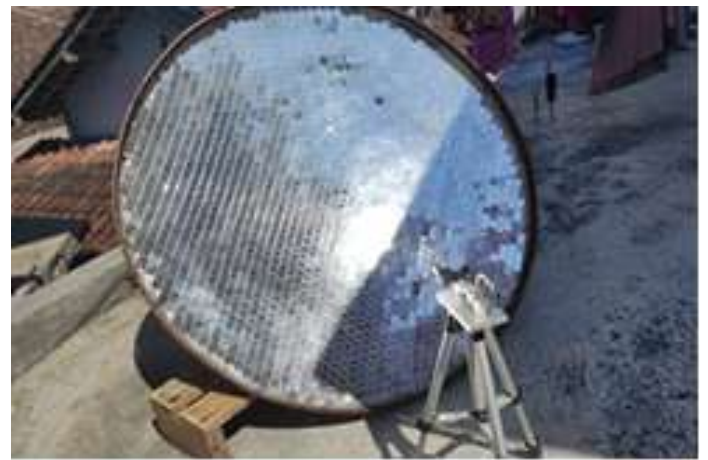

Gambar 2. Parabola reflektor berjenis dish.

Pada gambar 2, parabola reflektor berjenis dish terbuat dari material utama berbahan dasar plat alumunium dengan ketebalan 2,3 $\mathrm{mm}$ yang dibentuk elipsoidal dengan diameter $960 \mathrm{~mm}$ dan ketinggian $100 \mathrm{~mm}$. Permukaan sisi dalam parabola reflektor dilapisi dengan kaca cermin berbentuk persegi dengan ukuran luas $1 \mathrm{~m}^{2}$ yang direkatkan menggunakan sealant.

Secara teroritis perhitungan focal point yang dihasilkan adalah :

$$
\begin{aligned}
& Y=\frac{x^{2}}{4 a} \\
& Y=\frac{(480 \mathrm{~mm} \times 480 \mathrm{~mm})^{2}}{4 \times 100 \mathrm{~mm}} \\
& Y=\frac{230.400 \mathrm{~mm}^{2}}{400 \mathrm{~mm}} \\
& Y=576 \mathrm{~mm} \\
& Y=0.57 \mathrm{~m}
\end{aligned}
$$

Unjuk kerja parabola reflektor dalam memantulkan radiasi matahari digunakan pada jam 10:00 sampai dengan 11:40 WIB dalam kondisi yang cerah karena pada jam tersebut nilai intensitas radiasi yang didapatkan lebih optimal. Perhitungan nilai intensitas matahari diukur menggunakan solarimeter dalam bentuk lux yang kemudian dikonversikan ke dalam satuan $\mathrm{W} / \mathrm{m}^{2}$. 
b. Mesin striling tipe gamma

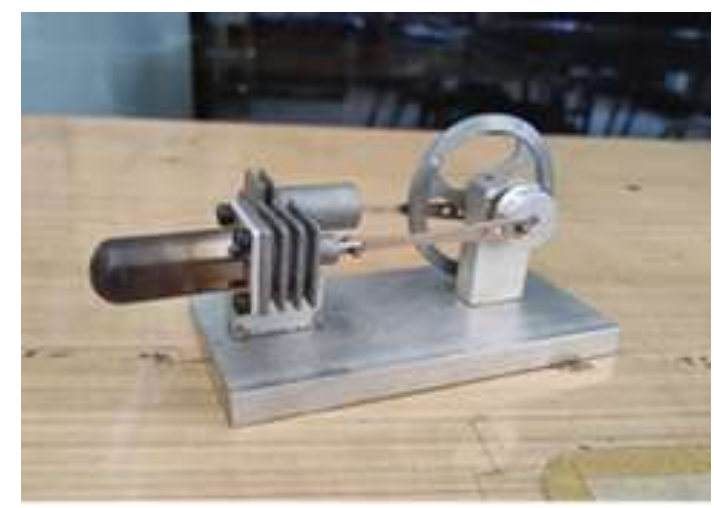

Gambar 3. Mesin stirling tipe gamma menggunakan hot cylinder dengan material stainless steel.

Pembuatan mesin stirling tipe gamma memiliki dua silinder yang terpasang secara terpisah meliputi hot cylinder dan cold cylinder namun tetap terhubung dalam satu poros engkol yang sama. Mesin stirling tipe gamma yang dibuat memiliki spesifikasi sebagai berikut :

Tabel 1. Spesifikasi mesin stirling.

\begin{tabular}{ccc}
\hline No & Item & Spesifikasi \\
\hline 1 & Displacer bore & $14 \mathrm{~mm}$ \\
\hline 2 & Displacer stroke & $12 \mathrm{~mm}$ \\
\hline 3 & Swept volume displacer & $718 \mathrm{~mm}^{3}$ \\
\hline 4 & Power piston bore & $8 \mathrm{~mm}$ \\
\hline 5 & Power piston stroke & $12 \mathrm{~mm}$ \\
\hline 6 & Swept volume piston & $201 \mathrm{~mm}^{3}$ \\
\hline 7 & Phase Angle & $90^{\circ}$ \\
\hline 8 & Working Gas & Air \\
\hline 9 & Gas constant & $287 \mathrm{~J} / \mathrm{Kg} . \mathrm{K}$ \\
\hline
\end{tabular}

c. Material hot cylinder

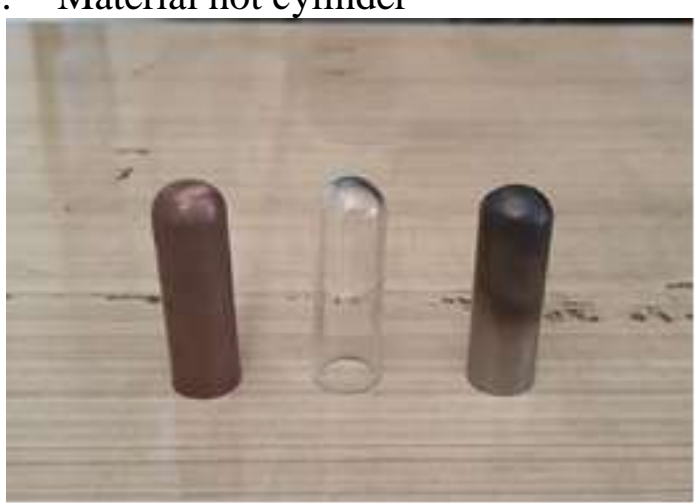

Gambar 4. Material hot cylinder mesin stirling tipe gamma.

Pada penelitian ini penggunaan tiga jenis material pada hot cylinder meliputi copper, stainless steel, dan glass dengan konduktivitas yang berbeda sesuai tabel dibawah ini :

Tabel 2. Konduktivitas termal material.

\begin{tabular}{clc} 
No. & \multicolumn{1}{c}{ Material } & $\begin{array}{c}\text { Konduktivitas } \\
\text { termal }\end{array}$ \\
\hline 1 & Copper & $379,0 \mathrm{~W} / \mathrm{m} .{ }^{\circ} \mathrm{C}$ \\
2 & Stainless Steel & $16,0 \mathrm{~W} / \mathrm{m} .{ }^{\circ} \mathrm{C}$ \\
3 & Glass & $0,78 \mathrm{~W} / \mathrm{m} .{ }^{\circ} \mathrm{C}$ \\
\hline
\end{tabular}

\section{Teknik Pengambilan Data}

Pengambilan data pada penelitian ini dilakukan diluar ruangan saat kondisi siang hari dengan mengamati perubahan intensitas matahari. Adapun langkah-langkah yang digunakan dalam proses pengambilan data antara lain :

1. Memposisikan mesin stirling pada titik focal point reflektor parabolik untuk mendapatkan panas energi matahari yang terkonsentrasi.

2. Menempatkan semua alat ukur pada variabel pengambilan data seperti termometer digital yang dihubungkan pada termokopel yang diletakan pada hot cylinder dan cold cylinder, tachometer pada sisi depan flywheel untuk mengetahui putaran RPM, neraca pegas yang dihubungkan pada crankshaft untuk mengetahui nilai torsi, dan stopwatch untuk menghitung durasi unjuk kerja mesin stirling pada tiap prosesnya.

3. Melakukan pencatatan terhadap parameter pengukuran meliputi : temperatur hot cylinder, temperatur suhu cold cylinder, rpm, dan pada setiap jenis material hot cylinder (stainless steel, copper, \& glass).

4. Pengambilan data ini dilakukan selama 3 hari untuk masing-masing variabel jenis material pada hot cylinder yang digunakan.

\section{Hasil dan Pembahasan}

Unjuk kerja mesin stirling tipe gamma bekerja dengan memanfaatkan energi alternatif berupa radiasi termal matahari yang di pantulkan oleh parabola 
relflektor berjenis dish secara terkonsentrasi menuju ujung hot cylinder. Energi panas yang diterima oleh hot cylinder mesin stirling kemudian dikonversi menjadi energi gerak melalui sistem regenerasi tertutup, dimana fluida kerja yang ada didalam sistem akan terkompresi atau terekspansi pada reservoir yang terpisah secara konveksi. Proses ini meyebabkan perubahan temperatur, perbedaan tekanan, dan volume yang kemudian di distribusikan untuk menggerakan piston daya. Gerak yang dihasilkan secara translasi diubah menjadi gerak rotasi pada flywheel.

Berdasarkan data pengujian didapatkan hasil sebagai berikut :

Tabel 3. Hasil pengujian material copper

\begin{tabular}{ccccccc}
\hline \multirow{2}{*}{ No. } & \multirow{2}{*}{ Jam } & \multicolumn{2}{c}{ Suhu $\left({ }^{\circ} \mathrm{C}\right)$} & \multirow{2}{*}{ Hot $\left({ }^{\circ} \mathrm{C}\right)$} & Rpm & Torsi \\
& & Cold & & & $($ N.mm $)$ \\
\hline 1 & $10: 00$ & 27,2 & 26,9 & 0,3 & 0 & 0 \\
2 & $10: 20$ & 51,4 & 31 & 20,4 & 0 & 0 \\
3 & $10: 40$ & 106 & 51 & 55 & 0 & 0 \\
4 & $11: 00$ & 139 & 56 & 83 & 0 & 0 \\
5 & $11: 20$ & 161 & 57 & 104 & 0 & 0 \\
6 & $11: 37$ & 175 & 60 & 115 & 106 & 0,69 \\
\hline
\end{tabular}

Pada tabel 3, hasil unjuk kerja mesin stirling pada percobaan hari pertama dengan menggunakan material copper yang memiliki konduktivitas panas sebesar 379 $\mathrm{W} / \mathrm{m}^{2}$ dapat beroperasi di jam 11:37 WIB dengan perbedaan temperatur sebesar $115^{\circ} \mathrm{C}$ dan menghasilkan kecepatan putaran sebesar $106 \mathrm{rpm}$ serta torsi sebesar 0,69 N.mm.

Tabel 4. Hasil pengujian material stainless

\begin{tabular}{ccccccc}
\multicolumn{7}{c}{ steel } \\
\cline { 1 - 6 } No. & \multirow{2}{*}{ Jam } & \multicolumn{2}{c}{ Suhu $\left({ }^{\circ} \mathrm{C}\right)$} & \multirow{\Delta}{*}{$\begin{array}{c}\Delta \mathrm{T} \\
\left({ }^{\circ} \mathrm{C}\right)\end{array}$} & Rpm & $\begin{array}{c}\text { Torsi } \\
(\text { N.mm })\end{array}$ \\
\cline { 3 - 6 } & Hot & Cold & & 0 & 0 \\
\hline 1 & $10: 00$ & 26,9 & 26,9 & 0 & 0 & 0 \\
\hline 2 & $10: 20$ & 72.4 & 34 & 38,4 & 0 & 0 \\
\hline 3 & $10: 40$ & 127 & 45 & 82 & 0 & 0 \\
\hline 4 & $10: 54$ & 155 & 52 & 103 & 124 & 0,60 \\
\hline 5 & $11: 20$ & 157 & 58 & 99 & 0 & 0 \\
\hline 6 & $11: 40$ & 157 & 60 & 97 & 0 & 0 \\
\hline
\end{tabular}

Pada tabel 4, hasil unjuk kerja mesin stirling pada percobaan hari kedua dengan menggunakan material stainless steel yang memiliki konduktivitas panas sebesar 16 $\mathrm{W} / \mathrm{m}^{2}$ dapat beroperasi di jam 10:54 WIB dengan perbedaan temperatur sebesar $103^{\circ} \mathrm{C}$ dan menghasilkan kecepatan putaran sebesar $124 \mathrm{rpm}$ serta torsi sebesar 0,60 N.mm.

Tabel 5. Hasil pengujian material glass

\begin{tabular}{ccccccc}
\hline \multirow{2}{*}{ No. } & \multirow{2}{*}{ Jam } & \multicolumn{2}{c}{ Suhu $\left({ }^{\circ} \mathrm{C}\right)$} & \multirow{2}{*}{$\left({ }^{\circ} \mathrm{C}\right)$} & \multirow{2}{*}{ Rpm } & Torsi \\
& & Hot & Cold & N.mm $)$ \\
\hline 1 & $10: 00$ & 27,3 & 26,9 & 0,4 & 0 & 0 \\
2 & $10: 20$ & 45,4 & 28 & 17,4 & 0 & 0 \\
3 & $10: 40$ & 84,6 & 36 & 48,6 & 0 & 0 \\
4 & $11: 00$ & 115 & 39 & 76 & 0 & 0 \\
5 & $11: 15$ & 132 & 44 & 88 & 131 & 0,57 \\
6 & $11: 40$ & 134 & 48 & 86 & 0 & 0 \\
\hline
\end{tabular}

Pada tabel 5, hasil unjuk kerja mesin stirling pada percobaan hari ketiga dengan menggunakan material glass yang memiliki konduktivitas panas sebesar $0,78 \mathrm{~W} / \mathrm{m}^{2}$ dapat beroperasi di jam 11:15 WIB dengan perbedaan temperatur sebesar $88^{\circ} \mathrm{C}$ dan menghasilkan kecepatan putaran sebesar $131 \mathrm{rpm}$ serta torsi sebesar 0,57 N.mm.

\section{Perhitungan tekanan kerja}

Tekanan kerja yang terjadi didalam mesin stirling tipe gamma di hitung menggunakan teori Schmidt pada setiap fase. Ada pun contoh perhitungan dilakukan pada mesin stirling tipe gama dengan menggunakan hot cylinder material glass pada masing-masing titik sebagai berikut :

Diketahui :

$$
\begin{aligned}
\mathrm{T}_{1} & =\mathrm{T}_{2}=\mathrm{T}_{\mathrm{C}}=44^{\circ} \mathrm{C}=317^{\circ} \mathrm{K} \\
\mathrm{T}_{3} & =\mathrm{T}_{4}=\mathrm{T}_{\mathrm{H}}=132^{\circ} \mathrm{C}=405^{\circ} \mathrm{K} \\
\mathrm{V}_{1} & =\mathrm{V}_{4}=\mathrm{V}_{\max }=2.8260 \mathrm{E}-06 \mathrm{~m}^{3} \\
\mathrm{~V}_{2} & =\mathrm{V}_{3}=\mathrm{V}_{\min }=2.2231 \mathrm{E}-06 \mathrm{~m}^{3}
\end{aligned}
$$

Tekanan pada titik 1 :

$\mathrm{P} 1=101,325 \mathrm{kPa}$

Tekanan pada titik 2 :

$$
\begin{aligned}
\mathrm{P} 2 & =\frac{\mathrm{P} 1 \cdot \mathrm{V} 1}{\mathrm{~V} 2} \\
& =\frac{101,325 \mathrm{kPa} \cdot 2,8260 \mathrm{E}-06 \mathrm{~m}^{3}}{2,2231-06 \mathrm{~m}^{3}} \\
& =128,803 \mathrm{kPa}
\end{aligned}
$$

Tekanan pada titik 3 :

$$
\mathrm{P} 3=\frac{\mathrm{P} 2 \cdot \mathrm{T} 3}{\mathrm{~T} 2}
$$




$$
\begin{aligned}
& =\frac{128,802 \mathrm{kPa} \cdot 405^{\circ} \mathrm{K}}{317^{\circ} \mathrm{K}} \\
& =164,559 \mathrm{kPa}
\end{aligned}
$$

Tekanan pada titik 4 :

$$
\begin{aligned}
\mathrm{P} 4 & =\frac{\mathrm{P} 3 \cdot \mathrm{V} 3}{\mathrm{~V} 4} \\
& =\frac{164,558 \mathrm{kPa} \cdot 2,2231-06 \mathrm{~m}^{3}}{2,8260 \mathrm{E}-06 \mathrm{~m}^{3}} \\
& =129,453 \mathrm{kPa}
\end{aligned}
$$

Dari perhitungan diatas didapat diagram PV pada material Glass sebagai berikut:

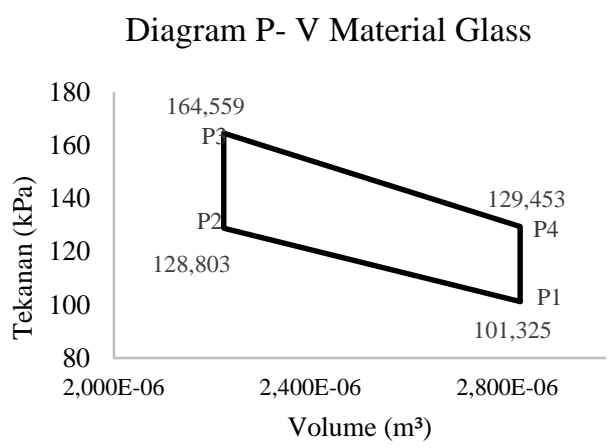

Gambar 5. Diagram P-V menggunakan hot cylinder material glass.

Contoh hasil perhitungan diatas dapat disimpulkan bahwa semakin besar perbedaan temperatur pada hot cylinder dan cold cylinder menyebabkan tekanan kerja mesin stirling akan semakin tinggi.

\section{Perhitungan laju perpindahan panas}

Laju perpindahan panas yang terjadi pada mesin stirling dihitung dengan batasan kondisi termodinamika karena adanya perbedaan konduktivitas material antara hot cylinder dengan cold cylinder. Perpindahan panas yang terjadi berlangsung secara konveksi dari luar hot cylinder kemudian diteruskan lewat hot cylinder secara konduksi dan selanjutnya ke zat alir yang menuju ke cold cylinder secara konveksi.

Contoh laju perpindahan panas yang terjadi pada material glass ditunjukan pada perhitungan sebagai berikut :

Diketahui :

Konduktivitas termal $\mathrm{K}=0,78 \mathrm{~W} / \mathrm{m} .{ }^{\circ} \mathrm{C}$

Jari - jari dalam $\mathrm{r}_{1} \quad=0,006 \mathrm{~m}$
Jari - jari dalam $\mathrm{r}_{2} \quad=0,007 \mathrm{~m}$

Koefisien konveksi h $=10 \mathrm{~W} / \mathrm{m} .{ }^{\circ} \mathrm{C}$

Panjang silinder $\mathrm{L} \quad=0,04 \mathrm{~m}$

Temperatur hot $\mathrm{T}_{\mathrm{A}} \quad=132{ }^{\circ} \mathrm{C}$

Temperatur cold $\mathrm{T}_{\mathrm{B}} \quad=44{ }^{\circ} \mathrm{C}$

$$
\begin{aligned}
\mathrm{q}= & \frac{2 \pi \mathrm{L}(\mathrm{TA}-\mathrm{TB})}{\frac{1}{\mathrm{~h} 1 \mathrm{r} 1}+\frac{\ln (\mathrm{r} 2 / \mathrm{r} 1)}{\mathrm{k}}+\frac{1}{\mathrm{~h} 2 \mathrm{r} 2}} \\
= & \frac{2 \pi \cdot 0,04(132-44)}{\frac{1}{0,06}+\frac{\ln (0,007 / 0,006)}{0,78}+\frac{1}{0,07}} \\
= & 0,71 \mathrm{~W} \text { Dengan menggunakan koefisien }
\end{aligned}
$$
perpindahan panas menyeluruh dapat disimpulkan bahwa dengan konduktivitas material yang lebih tinggi maka laju perpindahan panas yang terjadi akan semakin tinggi dan sebaliknya material yang cenderung bersifat isolator dengan konduktivitas panas yang lebih rendah menghasilkan laju perpindahan panas yang lebih rendah.

\section{Grafik analisa hubungan antara perbedaan temperatur, waktu, rpm, torsi dan efisiensi.}

Pengaruh konduktivitas material hot cylinder pada unjuk kerja mesin stirling tipe gamma dengan menggunakan energi surya terkonsentrasi dihubungkan dengan parameter perhitungan yang dianalisis dengan beberapa grafik sebagai berikut:

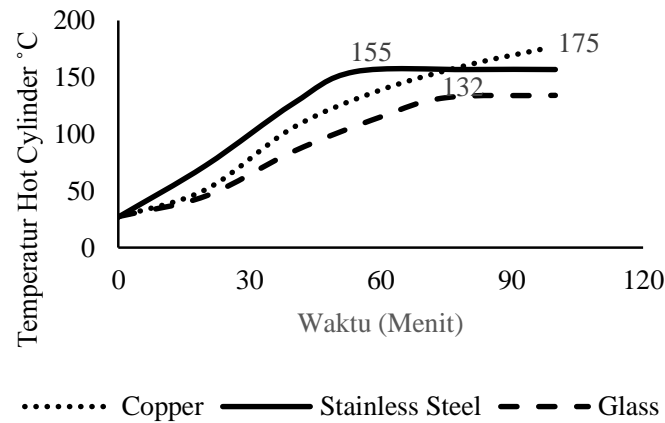

Gambar 4. Grafik hubungan antara perubahan temperatur pada hot cylinder terhadap waktu.

Pada grafik diatas material copper dengan konduktivitas tertinggi sebesar 379 $\mathrm{W} / \mathrm{m}^{\circ} \mathrm{C}$ memerlukan waktu selama 97 menit 
dengan temperatur pada hot cylinder sebesar $175^{\circ} \mathrm{C}$ untuk mengoperasikan mesin stirling. Kondisi tersebut menunjukan bahwa semakin tinggi nilai konduktivitas material maka unjuk kerja mesin stirling jika dihitung dalam satuan waktu akan menjadi semakin lama.

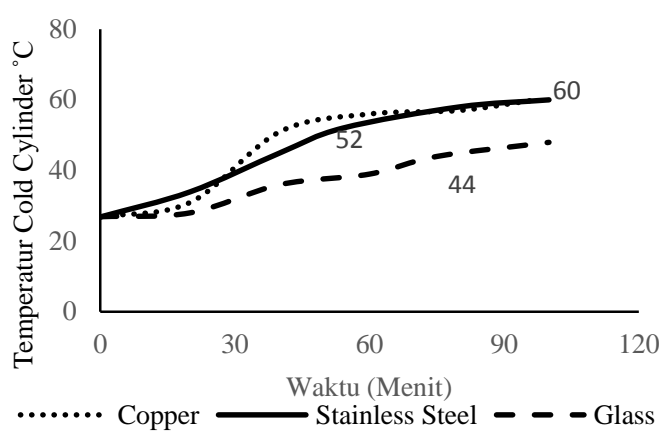

Gambar 6. Grafik hubungan antara perubahan temperatur pada cold cylinder terhadap waktu.

Pada cold cylinder sesuai grafik diatas menunjukan bahwa perpindahan panas yang terjadi pada hot cylinder material copper menuju cold cylinder memiliki temperatur yang lebih tinggi dengan waktu unjuk kerja mesin yang lebih lama, sementara material glass memiliki temperatur yang lebih rendah dengan waktu unjuk kerja mesin yang lebih cepat.

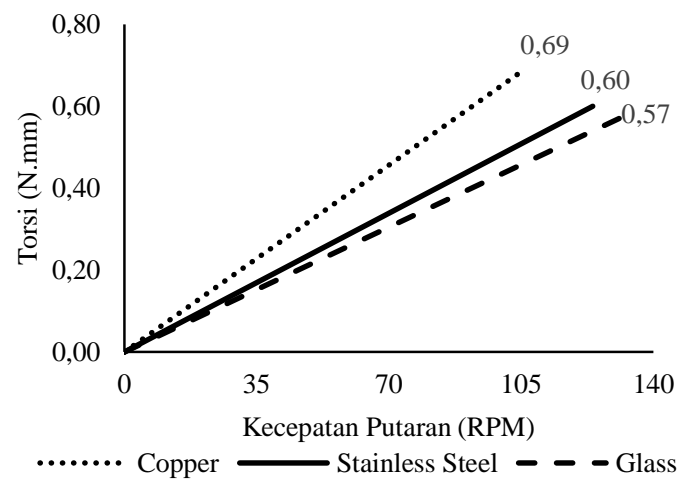

Gambar 7. Grafik hubungan antara kecepatan putaran terhadap torsi.

Pada grafik diatas material copper memiliki torsi tertinggi sebesar 0,69 N.mm dengan kecepatan putaran terendah sebesar $106 \mathrm{Rpm}$, sementara material glass memiliki torsi tendah sebesar 0,57 N.mm dengan kecepatan putaran tertinggi sebesar 131 Rpm. Pada material copper torsi tertinggi disebabkan karena adanya pengaruh tekanan yang dialami oleh sistem dimana sesuai dengan perhitungan analisa schmidt didapatkan nilai tekanan kerja tertinggi pada titik P3 atau proses kompresi isokhorik sebesar 173,284 $\mathrm{kPa}$. Sementara pada material glass memiliki torsi terendah dikarenakan tekanan kerja mesin pada titik P3 sebesar $164,559 \mathrm{kPa}$ atau lebih rendah daripada material lainnya. Hal ini membuktikan bahwa hubungan antara tekanan dan torsi berbanding lurus, semakin besar tekanan maka torsi yang dihasilkan akan semakin besar. Adanya perbedaan temperatur berpengaruh terhadap kecepatan putaran, pada material glass dengan perbedaan temperatur yang dihasilkan sebesar $88^{\circ} \mathrm{C}$ atau lebih rendah dari material copper menghasilkan kecepatan putaran tertinggi sebesar $103 \mathrm{rpm}$. Apabila nilai perbedaan temperatur pada material glass nilainya sama dengan perbedaan temperatur pada material copper maka nilai kecepatan putaran yang terjadi akan semakin tinggi lagi. Hal ini membuktikan bahwa semakin tinggi perbedaan temperatur maka rpm yang dihasilkan akan semakin tinggi.

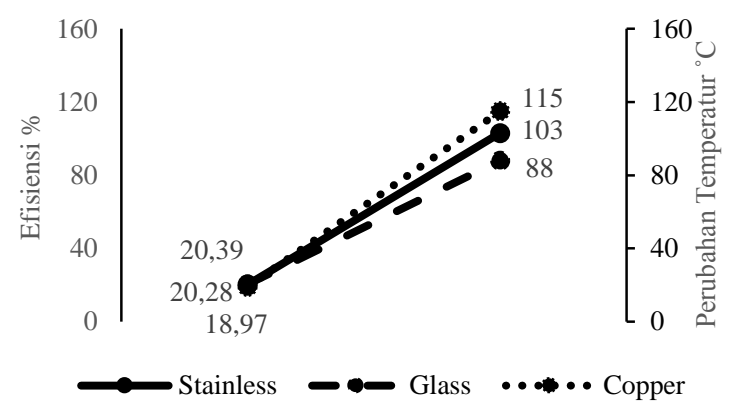

Gambar 8. Grafik hubungan antara kecepatan perubahan temperatur terhadap efisiensi.

Sesuai dengan kondisi grafik diatas material glass yang cenderung bersifat isolator dengan konduktivitas panas sebesar $0,78 \mathrm{~W} / \mathrm{m}{ }^{\circ} \mathrm{C}$ memiliki efisiensi tertinggi sebesar $20,39 \%$ pada perubahan temperatur terendah sebesar $88^{\circ} \mathrm{C}$ dari material lainnya. Hal yang mendasari fenomena tersebut dikarenakan material glass memiliki pengaruh dalam menyimpan panas yang lebih baik pada area hot cylinder sehingga laju perpindahan panas yang terjadi tidak cepat merambat secara konduksi pada 
bagian luar mesin stirling, melainkan cenderung berlangsung secara konveksi pada bagian dalam mesin stirling sesuai dengan prinsip kerjanya dimana di mana fluida kerja akan terkompresi atau terekspansi pada reservoir yang terpisah kemudian didistribusikan untuk menggerakan piston secara reciprocating.

\section{Kesimpulan}

Unjuk kerja mesin stirling tipe gamma bekerja dengan memanfaatkan energi alternatif berupa radiasi termal matahari yang di pantulkan oleh parabola relflektor berjenis dish secara terkonsentrasi menuju ujung hot cylinder. Energi panas yang diterima oleh hot cylinder mesin stirling kemudian dikonversi menjadi energi gerak melalui sistem regenerasi tertutup, dimana fluida kerja yang ada didalam sistem akan terkompresi atau terekspansi pada reservoir yang terpisah secara konveksi. Proses ini meyebabkan perubahan temperatur, perbedaan tekanan, dan volume yang kemudian di distribusikan untuk menggerakan piston daya. Gerak yang dihasilkan secara translasi diubah menjadi gerak rotasi pada flywheel.

Pengaruh penggunaan material glass yang cenderung bersifat isolator dengan konduktivitas panas sebesar $0,78 \mathrm{~W} / \mathrm{m}{ }^{\circ} \mathrm{C}$ memiliki efisiensi tertinggi sebesar 20,39\% pada perubahan temperatur terendah sebesar $88{ }^{\circ} \mathrm{C}$ dari material lainnya. Hal tersebut dikarenakan material glass mampu menyimpan panas yang lebih baik pada area hot cylinder sehingga laju perpindahan panas yang terjadi tidak cepat merambat secara konduksi pada bagian luar mesin stirling, melainkan cenderung berlangsung secara konveksi pada bagian dalam mesin stirling.

\section{Referensi}

[1] A. M. Karunia, "5 Bisnis yang Bakal Bersinar Versi Ignasius Jonan," https://money.kompas.com/, 2020. .

[2] S. Hamdi, "Mengenal Lama Penyinaran Matahri Sebagai Salah
Satu Parameter Klimatologi," Unisia, 2014.

[3] M. N. Majid, N. R. Ismail, and P. Swandono, "Pengaruh ukuran serbuk kayu jati dan suhu pemanasan terhadap volume dan ilai kalor tar pada proses pirolisis," vol. 16, no. 2, pp. 1-6, 2021.

[4] Anon, "Stirling Engines.," C. Chart. Mech. Eng., vol. 29, no. 6, pp. 59-62, 1982.

[5] N. Kurniawati, "Penentuan Konduktivitas Termal Pada Beberapa Jenis Logam.” pp. 38-48, 1999.

[6] S. Kang, M. Kuo, J. Chen, and W. Lu, "Fabrication and Test of GammaType Stirling Engine."

[7] A. Zayyinun and M. Widyartono, "Prototipe Mesin Stirling Menggunakan Panas Sinar Matahari Sebagai Energi Alternatif," Tek. Elektro, vol. 09, no. 2, pp. 459-466, 2020.

[8] A. Bhagat, A. Modi, P. Hinganikar, P. Tambekar, N. U. Kakade, and B. N. Kale, "Design of Alpha Stirling Engine in Conjunction with Solar Concentrator," Int. Res. J. Eng. Technol., vol. 3, no. 4, pp. 261-266, 2016.

[9] Z. F. Alfianti, "Desain Dan Pembuatan mesin Stirling Tenaga Matahari Dengan Memanfaatkan Pemanas Matahari Tipe Box Untuk Pembangkit Listrik," p. 73, 2016.

[10] H. S. Ritonga, "Rancang Bangun Mesin Stirling Tipe Gama Berkapasitas $157 \mathrm{ml}$ Menggunakan Sistem Pendingin Fluida Cair," no. 1, pp. 12-20, 2019.

[11] F. Siddiqui, N. Hayat, M. Farhan, M. Farooq, and H. Bilal, "Effect of phase angle on the efficiency of beta type Stirling engine," J. Fac. Eng. Technol., vol. 22, no. 2, pp. 99-109, 2009.

[12] I. Ali, I. M. Saleh, K. Khalifa, M. Bughazem, and N. Algharbi, "Developments in Parabolic Solar Dish Concentrator For Enhanced 
System Efficiency of Steam Generation," Dev. Parabol. Sol. Dish Conc. Enhanc. Syst., vol. 6, no. 1, pp. 17-32, 2016.

[13] I. A. D. Astuti, "Penentuan Konduktivitas Termal Logam Tembaga, Kuningan, dan Besi dengan Metode Gandengan," Pros. Semin. Nas. Fis. dan Pendidik. Fis. Ke-6 2015, vol. 6, no. 1, pp. 23027827, 2015.

[14] S. Janti, "Prosiding Seminar Nasional Aplikasi Sains \& Teknologi (SNAST) 2014 Yogyakarta, 15 November 2014 ISSN: 1979-911X," Snast, no. November, pp. 211-216, 2014. 